\title{
Rectal Hyperplastic Polyp
}

National Cancer Institute

\section{Source}

National Cancer Institute. Rectal Hyperplastic Polyp. NCI Thesaurus. Code C5619.

A serrated polypoid lesion that arises in the rectum. It rarely produces symptoms. This group includes goblet cell rich, mucin poor, and microvesicular hyperplastic polyps. 